\title{
ASSESSING QUALITY OF LIFE AND DEPRESSION AMONG PEOPLE LIVING WITH HIVIAIDS AND TB-HIV COINFECTION IN KATHMANDU, NEPAL
}

\author{
Timilsina $\mathbf{S}^{1}$, Regmi K \\ ${ }^{1}$ District AIDS Coordination Committee, District Health Office, Nuwakot, Nepal \\ ${ }^{2}$ District AIDS Coordination Committee, District Health Office, Arghakhachi, Nepal
}

\begin{abstract}
Introduction: Assessing the health related quality of life (HQL) and depression in human immunodeficiency virus (HIV) positive people and TB-HIV coinfected people is of extreme importance in designing strategies and implementing interventional programs on treatment care and support to People living with HIV and AIDS.
\end{abstract}

Methodology: A cross-sectional study was conducted among People living with HIVIAIDS and TB-HIV Coinfection from July to December 2011 at care and support canters in Kathmandu, Nepal. The list HIV care and Support centre registered at Kathmandu were selected using the lottery proportionately to meet the sample size of 154 . The method of data collection was summarized in the World Health Organization's questionnaire for Health related Quality of life and Beck Depression Inventory Scale II for depression. Data was collected using verbal information of respondents, entered on Epi Data version 3.4.1 and analyzed using SPSS version 16.0.

Results: TB-HIV coinfected people had lower quality of life in all domains compared to HIVIAIDS infected people. The prevalence of depression was found higher in TB-HIV coinfected people than HIVIAIDS group. CD4 count, educational status, occupation, ethnicity, family size and depression were statistically significant with the QoL domains. Among coinfected patients, depression was 3.86 times more likely to influence QoL while adjusted odds ratio was 4.21 times higher.

Conclusion: The TB control program should design strategies to improve the quality of life of TB-HIV coinfected people and depression should be targeted as an intervention to improve the quality of life of people living with HIV with or without TB.

Key words: Nepal, World Health Organization, Quality of Life Instrument, Beck Depression Inventory-II

\section{INTRODUCTION}

With the detection of Human Immunodeficiency Virus (HIV) for the first time in Nepal in 1988, HIVI AIDS is now increasingly considered as a chronic disease and is in the stage of a concentrated epidemic. Tuberculosis, more commonly known as TB, is a bacterial infection that usually affects the lungs but can affect any part of the body

\footnotetext{
Correspondence:

Ms. Sabina Timilsina

District Coordinator

District AIDS Coordination Committee

Nuwakot, Nepal

E-mail: dacc.nuwakot@gmail.com
}

except hair, teeth and nails and is one of the main causes of HIV-related morbidity and mortality. ${ }^{1}$ When a person is infected with HIV, they are at an increased risk of also contracting TB. Co-infection with TB can also mean an accelerated progression to AIDS. A HIV-negative person with a latent TB infection has a $10 \%$ chance of progressing to active TB over his or her entire lifetime, whereas a HIVpositive person has a $10 \%$ chance of developing active TB each year. ${ }^{2}$ Many of the TB-HIV and HIV patients struggle with numerous social problems such as stigma, poverty, depression, substance abuse, and cultural beliefs which can affect their QoL not only from the physical health aspect, but also from a mental and social health point of view, and this causes numerous problems relating to the 
patients' useful activities and interests. Assessing health-related quality of life (HQoL) is useful for documenting the patients' perceived burden of chronic disease, tracking changes in health over time, assessing the effects of treatment and quantifying the return on health care investment. The World Health Organization (WHO) has defined quality of life "as an individual's perception of their position in life in the context of the culture and value systems in which they live and in relation to their goals, expectations, standards and concerns". According to WHO "Depression is a common mental disorder that presents with depressed mood, loss of interest or pleasure, feelings of guilt or low selfworth, disturbed sleep or appetite, low energy, and poor concentration. These problems can become chronic or recurrent and lead to substantial impairments in an individual's ability to take care of his or her everyday responsibilities."The unparallel magnitude and scale of the HIVI AIDS and TB epidemic remain major public health challenges globally. ${ }^{3}$ Nepal has a concentrated HIV and AIDS epidemic, with an estimated 61,000 persons living with HIV and AIDS and about 14 new HIV infections each day. ${ }^{4}$ The estimated prevalence of HIV among TB patients between the ages of 15-49 years and the estimated number of active TB cases among PLHIV in Nepal is $2.4 \%{ }^{5}$ The assessment of QoL is central to understanding how people's lives are affected by TB and HIV infection. Optimization of HQoL is particularly important now that TB and HIV Coinfection can be considered a chronic disease with the prospect of long-term survival. The assessment of HQoL in this population can help us to detect problems that may influence the progression of the disease.

\section{METHODS}

\section{Study Design}

The study was cross sectional in nature and was prepared with the aid of quantitative data.The study was conducted at care and support centre i.e. Prerana, Navakiran Plus, Genetup, National Association of PLHA in Nepal $(\mathrm{NAP}+\mathrm{N})$ for 6 months starting from July 2011.

\section{Study Population}

The study population included people above 16 years including men and women with HIVIAIDS and TB-HIV Coinfection.

\section{Inclusion and Exclusion Criteria}

The study subjects above 16 years who had the history of HIVIAIDS and TB-HIV co-infection were included in the study. However the study subjects below 16 years and with auditory, visual and cognitive disability were not included in the study. Besides this, those who were unwilling to disclose the required information were excluded and unavailability of respondents was considered.

\section{Sampling Method and size}

The sample population was 154 including the 10\% of non response rate at $95 \%$ confidence interval. The Random sampling technique followed by systematic selection of respondent was used by following procedure:

1. List of care and support centres present at Kathmandu valley were ranked anonymously and four care and support centres were chosen to meet the required sample size proportionately from the lottery.

2. Systematic sampling Method was done to select the respondents at this care and support centers.

3. During administration of questionnaire $50 \%$ of PLWHA were women.

4. Unavailability of respondents was addressed by keeping ten extra optionally selected samples at step 2 .

\section{Data Collection Procedure}

The data was collected by interviewing the respondents using a structured questionnaire WHOQoL-HIV BREF ${ }^{6}$ instrument consists of 31 items, with each item using a 5-point Likert scale and Beck Inventory Depression Scale $\mathrm{II}^{7}$ which has 21 items.

\section{Validity and Reliability}

The study was conducted using the WHO health related quality of life indicator (HQoL) and Beck Inventory Depression Scale II which is valid, widely used and the most accepted instrument. Besides this, the pre testing was performed in order to check the acceptability of the questionnaire with the respondents. To measure internal consistency, the Cronbach's alpha was calculated for each domain of the instrument. Physical and Level of independence domains of WHOHQoL BREF questionnaire had a high value of Cronbach's alpha $(a>0.7)$ i.e. 0.78 and 0.72 . However, all of the other 
remaining had an average value of Cronbach's alpha that is psychological health 0.68 , social relationship 0.64 , environmental 0.64 , spiritual/ personal beliefs 0.66 and overall satisfaction 0.63 .

\section{Data Processing and Analysis}

The data was entered in Epi data version 3.4.1 and analysis was done using SPSS version 16. Descriptive statistics for continuous data and frequencies \& proportion for categorical data were calculated. For inferential statistics, t-test and one way ANOVA were used for bivariate analysis. Statistical significance was set at $p \leq 0.05$. Rank sum test and correlation were used for significant test and association. A binary logistic regression was performed to measure the strength of association between dependent and independent variables.

\section{Ethical Consideration}

The ethical approval was received from the Institutional Review Board of faculty of health science, Nobel College, Pokhara University. An informed verbal consent was ensured prior to administration of the questionnaire. The beneficence of the respondents was taken into consideration, subjects were not coerced to participate in the study and confidentiality was maintained. No incentives were provided for extraction of data. Cited references are presented in APA format for due acknowledgement of academic source and to avoid plagiarism.

\section{RESULTS}

\section{Sample Characteristics}

One hundred fifty four respondents were asked to participate in the study out of which $8(6 \%)$ refused to participate in the study. The overall response rate of participation in the study was high, $146(94 \%)$. The remaining participants refused to participate in the study explaining that they have participated in too many researches and few others said that they were not interested in our study.

Among all the participants $100 \%, 51.36 \%(n=75)$ were PLWHA and $48.63 \%$ ( $n=71$ ) were coinfected with TB-HIV. Majority of respondents $55.48 \%$ $(n=81)$ were males and were between the age of 26-35 years i.e. $48.63 \%(n=71)$ (table 1). $33.56 \%$ $(n=49)$ of the respondents had secondary level of schooling. As per the marital status $50 \%(n=73)$ of the respondents were married followed by single, separated and divorced $1.54 .11 \%(n=79)$ of the respondents have CD4 count less than 350 other than $45.90 \%$ ( $n=67)$ have CD4 count more than 350 . Majority of the respondents i.e.68.50\% $(n=100)$ were employed and $56.16 \%(n=82)$ lived in nuclear family (table 2).

The mean score for the six domains of HQoL and overall satisfaction regarding the general quality of life was highest in the environmental domain in both groups (22.08 and 24.08) followed by the psychological domain, i.e. 13.25 and 14.88 , and the least in the physical and overall satisfaction domains. All the domains were found to have positive correlation with PLWHA and TB-HIV Coinfected people except the physical health domain in Coinfected people where no correlation was found.

The prevalence of depression among 71 TB-HIV Coinfected people and 75 PLWHA using beck depression scale was found to be $33.8 \%$ and $7.9 \%$ respectively (figure 1).

Depression and CD4 Count were associated with both the PLWHA and coinfected patients. Among coinfected patients, depression was 3.86 times more likely to influence $Q \mathrm{oL}$ while, adjusted odds ratio was 4.21 times higher, $\mathrm{OR}=4.211(95 \% \mathrm{Cl}$ : 1.22 , 14.47). No significant association was observed with the sex, occupation and occupational status in both the groups (table 3). 


\begin{tabular}{|c|c|c|c|c|c|c|c|}
\hline \multirow[t]{2}{*}{$\begin{array}{l}\text { Quality of life } \\
\text { domains }\end{array}$} & \multirow[t]{2}{*}{$\begin{array}{l}\text { Number } \\
\text { of items }\end{array}$} & \multirow{2}{*}{$\begin{array}{l}\text { TB-HIV Co- } \\
\text { infection } \\
\text { (n=71) Mean } \\
\text { (SD) }\end{array}$} & \multirow[t]{2}{*}{$\begin{array}{l}\text { Correlation } \\
\text { with total } \\
\text { score }\end{array}$} & \multirow{2}{*}{$\begin{array}{l}\text { HIV without TB/ } \\
\text { HIV Co-infection } \\
\text { ( } n=75) \text { Mean } \\
\text { (SD) }\end{array}$} & \multirow[t]{2}{*}{$\begin{array}{l}\text { Correlation } \\
\text { with total } \\
\text { score }\end{array}$} & \multicolumn{2}{|c|}{$\begin{array}{l}\text { Proportion of } \\
\text { respondents } \\
\text { with QoL score }\end{array}$} \\
\hline & & & & & & High & Low \\
\hline Physical Health & 4 & $11.99(1.80)$ & 0.041 & $11.52(2.05)$ & $0.385^{\star *}$ & 26.7 & 80.8 \\
\hline Psychological Health & 5 & $13.25(2.08)$ & $0.515^{\star *}$ & $14.88(2.24)$ & $0.590^{* *}$ & 37 & 89.7 \\
\hline Level of Independence & 4 & $12.77(1.46)$ & $0.406^{* *}$ & $12.97(1.77)$ & $0.467^{* *}$ & 42.5 & 86.3 \\
\hline Social Relationship & 4 & $11.79(2.47)$ & $0.744^{* *}$ & $13.36(2.41)$ & $0.680^{* *}$ & 35.6 & 85.6 \\
\hline Environmental & 8 & $22.08(2.96)$ & $0.773^{* *}$ & $24.08(2.71)$ & $0.597^{\text {** }}$ & 26 & 80.1 \\
\hline Spiritual & 4 & $11.08(2.48)$ & $0.772^{* *}$ & $13.09(2.59)$ & $0.725^{* *}$ & 25.3 & 81.1 \\
\hline Overall satisfaction & 2 & $5.25(2.01)$ & $0.783^{* *}$ & $7.07(1.51)$ & $0.507^{* *}$ & 33.1 & 81.2 \\
\hline
\end{tabular}
$p^{*}<0.05^{* *} p<0.001$

\begin{tabular}{|c|c|c|c|c|c|c|c|c|c|}
\hline Variables & $\begin{array}{c}\text { Sample } \\
\text { characteristics (\%) }\end{array}$ & $\mathrm{PH}$ & Psy & Spri & Social & Env & Variables & Ind & $\begin{array}{c}\text { Overall } \\
\text { satisfaction }\end{array}$ \\
\hline $\begin{array}{l}\text { Sex } \\
\text { Male } \\
\text { Female } \\
\text { T test } \\
\end{array}$ & $\begin{array}{l}55.48 \\
44.52\end{array}$ & $\begin{array}{r}11.53 \\
12.02 \\
-1.501 \\
\end{array}$ & $\begin{array}{l}14.16 \\
14.00 \\
0.416\end{array}$ & $\begin{array}{l}12.30 \\
11.89 \\
0.890\end{array}$ & $\begin{array}{l}12.75 \\
12.40 \\
0.827\end{array}$ & $\begin{array}{r}22.83 \\
23.46 \\
-1.273 \\
\end{array}$ & $\begin{array}{c}\text { Sex } \\
\text { Male } \\
\text { Female } \\
\text { U test }\end{array}$ & $\begin{array}{c}13.00 \\
13.00 \\
2546.0\end{array}$ & $\begin{array}{c}6.00 \\
6.00 \\
2604.5\end{array}$ \\
\hline $\begin{array}{l}\text { Age } \\
16-25 \\
26-35 \\
36-45 \\
46-55 \\
\text { F-test }\end{array}$ & $\begin{array}{c}17.80 \\
48.63 \\
28.09 \\
5.48\end{array}$ & $\begin{array}{l}11.88 \\
11.66 \\
11.80 \\
12.25 \\
0.353 \\
\end{array}$ & $\begin{array}{l}13.96 \\
14.10 \\
14.10 \\
14.38 \\
0.067\end{array}$ & $\begin{array}{l}12.12 \\
11.90 \\
12.46 \\
12.45 \\
0.370\end{array}$ & $\begin{array}{l}12.38 \\
12.59 \\
12.78 \\
12.38 \\
0.147\end{array}$ & $\begin{array}{l}23.73 \\
23.28 \\
22.37 \\
22.38 \\
1.320 \\
\end{array}$ & & $\begin{array}{l}12.96 \\
12.97 \\
12.59 \\
13.25 \\
0.679\end{array}$ & $\begin{array}{l}6.38 \\
6.24 \\
5.93 \\
6.38 \\
0.356 \\
\end{array}$ \\
\hline $\begin{array}{l}\text { Educational Status } \\
\text { Primary } \\
\text { Lower secondary } \\
\text { Secondary } \\
\text { Above secondary } \\
\text { F-Test }\end{array}$ & $\begin{array}{c}17.80 \\
6.16 \\
\\
33.56 \\
27.38 \\
\end{array}$ & $\begin{array}{l}11.88 \\
12.44 \\
11.86 \\
10.88 \\
3.083^{*}\end{array}$ & $\begin{array}{l}13.35 \\
15.00 \\
14.35 \\
14.42 \\
2.302 \\
\end{array}$ & $\begin{array}{l}12.12 \\
12.22 \\
12.10 \\
12.95 \\
0.898 \\
\end{array}$ & $\begin{array}{l}12.23 \\
13.11 \\
12.57 \\
13.52 \\
1.793 \\
\end{array}$ & $\begin{array}{l}22.73 \\
23.56 \\
23.02 \\
23.58 \\
0.531 \\
\end{array}$ & & $\begin{array}{l}12.62 \\
12.56 \\
12.94 \\
12.80 \\
0.310 \\
\end{array}$ & $\begin{array}{c}5.50 \\
6.56 \\
6.06 \\
7.35 \\
6.518^{\star \star} \\
\end{array}$ \\
\hline $\begin{array}{l}\text { Marital Status } \\
\text { Married } \\
\text { Single } \\
\text { Separated } \\
\text { Divorced } \\
\text { F-Test }\end{array}$ & $\begin{array}{c}50.0 \\
30.82 \\
9.59 \\
9.59\end{array}$ & $\begin{array}{l}11.79 \\
11.47 \\
12.50 \\
11.64 \\
1.083\end{array}$ & $\begin{array}{l}14.07 \\
14.00 \\
14.36 \\
14.21 \\
0.099\end{array}$ & $\begin{array}{l}12.56 \\
11.76 \\
11.50 \\
11.57 \\
1.347\end{array}$ & $\begin{array}{l}13.03 \\
11.93 \\
12.00 \\
13.07 \\
2.159\end{array}$ & $\begin{array}{l}23.07 \\
22.98 \\
23.07 \\
23.79 \\
0.267\end{array}$ & & $\begin{array}{l}12.67 \\
13.02 \\
13.07 \\
13.29 \\
0.868\end{array}$ & $\begin{array}{c}6.01 \\
6.40 \\
5.93 \\
6.64 \\
0.678\end{array}$ \\
\hline $\begin{array}{l}\text { Current CD4 Count } \\
\text { (cells/mm }{ }^{3} \text { ) } \\
\leq 350 \\
>350 \\
\text { T-Test }\end{array}$ & $\begin{array}{l}45.90 \\
54.11\end{array}$ & $\begin{array}{c}11.85 \\
11.66 \\
.594\end{array}$ & $\begin{array}{c}13.07 \\
14.95 \\
5.328^{\star *}\end{array}$ & $\begin{array}{c}11.09 \\
12.99 \\
-4.457^{\star *}\end{array}$ & $\begin{array}{r}11.69 \\
13.37 \\
-4.168^{\star *}\end{array}$ & $\begin{array}{c}21.82 \\
24.20 \\
5.192^{\star \star}\end{array}$ & & $\begin{array}{l}12.64 \\
13.08 \\
1.616 \\
\end{array}$ & $\begin{array}{c}5.10 \\
7.10 \\
-6.978^{\star \star} \\
\end{array}$ \\
\hline $\begin{array}{l}\text { Occupation } \\
\text { Employed } \\
\text { Unemployed } \\
\text { T-Test }\end{array}$ & $\begin{array}{l}68.50 \\
31.50\end{array}$ & $\begin{array}{c}11.51 \\
12.26 \\
2.193^{*}\end{array}$ & $\begin{array}{c}14.36 \\
13.10 \\
2.114^{*}\end{array}$ & $\begin{array}{c}12.68 \\
10.89 \\
3.856^{\star *}\end{array}$ & $\begin{array}{c}13.27 \\
11.23 \\
5.073^{\star *}\end{array}$ & $\begin{array}{l}23.54 \\
22.17 \\
2.607^{*}\end{array}$ & & $\begin{array}{l}12.87 \\
12.89 \\
-.073\end{array}$ & $\begin{array}{c}6.53 \\
5.43 \\
3.192^{\star}\end{array}$ \\
\hline $\begin{array}{l}\text { Family Size } \\
\text { Nuclear } \\
\text { Joint } \\
\text { Single } \\
\text { F Test }\end{array}$ & $\begin{array}{l}56.16 \\
32.20 \\
11.64\end{array}$ & $\begin{array}{l}11.54 \\
12.21 \\
11.47 \\
2.023\end{array}$ & $\begin{array}{l}13.87 \\
14.45 \\
14.18 \\
0.958\end{array}$ & $\begin{array}{c}11.98 \\
12.49 \\
11.76 \\
.688\end{array}$ & $\begin{array}{c}12.56 \\
12.79 \\
12.24 \\
.304\end{array}$ & $\begin{array}{l}22.74 \\
23.96 \\
22.53 \\
2.878^{\star}\end{array}$ & $\begin{array}{l}\text { Family Size } \\
\text { Nuclear } \\
\text { Joint } \\
\text { Single } \\
\text { Kruskal wallis } \\
\text { test } \\
\end{array}$ & $\begin{array}{l}13.00 \\
13.00 \\
13.00 \\
0.559\end{array}$ & $\begin{array}{c}6.00 \\
6.00 \\
6.00 \\
3.400\end{array}$ \\
\hline $\begin{array}{l}\text { Depression } \\
\text { Minimal } \\
\text { Mild } \\
\text { Moderate } \\
\text { Severe } \\
\text { F Test }\end{array}$ & $\begin{array}{c}\text { Prevalence of } \\
\text { depression is } 41.7\end{array}$ & $\begin{array}{l}11.58 \\
12.80 \\
11.73 \\
12.27 \\
1.627\end{array}$ & $\begin{array}{l}14.58 \\
13.30 \\
13.07 \\
12.20 \\
7.066^{* \star}\end{array}$ & $\begin{array}{c}12.82 \\
11.90 \\
9.80 \\
9.60 \\
12.748^{* *}\end{array}$ & $\begin{array}{c}13.24 \\
11.90 \\
10.67 \\
10.47 \\
10.455^{* *}\end{array}$ & $\begin{array}{l}23.59 \\
22.90 \\
22.13 \\
20.80 \\
4.781^{*}\end{array}$ & & $\begin{array}{l}13.03 \\
12.70 \\
12.60 \\
12.20 \\
1.366\end{array}$ & $\begin{array}{c}6.58 \\
5.20 \\
4.13 \\
4.20 \\
21.504^{* *}\end{array}$ \\
\hline
\end{tabular}

${ }^{*} \mathrm{p}<0.05,{ }^{* *} \mathrm{p}<0.001, \mathrm{PH}=$ Physical health, $\mathrm{Psy}=$ psychological health, Social $=$ Social relationship, Env = Environment, Ind = level of independence, Spir $=$ Spiritual health 


\begin{tabular}{|c|c|c|c|c|c|}
\hline \multirow[t]{2}{*}{ Variables } & \multicolumn{2}{|c|}{ TB/ HIV Co-infection ( $n=71$ ) } & \multirow[t]{2}{*}{ Variables } & \multicolumn{2}{|c|}{ HIVIAIDS without TB $(n=75)$} \\
\hline & $\begin{array}{l}\text { Crude Odds } \\
\text { ratio }(95 \% \mathrm{Cl})\end{array}$ & $\begin{array}{l}\text { Adjusted Odds } \\
\text { ratio }(95 \% \mathrm{Cl})\end{array}$ & & $\begin{array}{l}\text { Crude Odds } \\
\text { ratio }(95 \% \mathrm{Cl})\end{array}$ & $\begin{array}{l}\text { Adjusted Odds } \\
\text { ratio }(95 \% \mathrm{Cl})\end{array}$ \\
\hline Sex & $\begin{array}{c}0.955 \\
(0.368-2.473)\end{array}$ & $\begin{array}{c}0.995 \\
(0.328-3.021)\end{array}$ & Sex & $\begin{array}{c}1.458 \\
(0.587-3.642)\end{array}$ & $\begin{array}{c}1.322 \\
(0.457-3.830)\end{array}$ \\
\hline Depression & $\begin{array}{c}3.860^{*} \\
(1.440-10.345)\end{array}$ & $\begin{array}{c}4.211^{*} \\
(1.225-14.478)\end{array}$ & Depression & $\begin{array}{c}2.259 \\
(0.896-5.698)\end{array}$ & $\begin{array}{c}1.858 \\
(0.686-5.026)\end{array}$ \\
\hline Occupation & $\begin{array}{c}0.410 \\
(0.156-1.080)\end{array}$ & $\begin{array}{c}0.756 \\
(0.238-2.398)\end{array}$ & Occupation & $\begin{array}{c}0.411 \\
(0.127-1.328)\end{array}$ & $\begin{array}{c}0.475 \\
(0.126-1.791)\end{array}$ \\
\hline CD4 Count & $\begin{array}{c}5.042^{*} \\
(1.268-20.053)\end{array}$ & $\begin{array}{c}0.188^{*} \\
(0.043-0.818)\end{array}$ & CD4 Count & $\begin{array}{c}0.095^{*} \\
(0.011-0.796)\end{array}$ & $\begin{array}{c}0.103^{*} \\
(0.012-0.891)\end{array}$ \\
\hline Educational status & $\begin{array}{c}1.381(0.425- \\
4.490)\end{array}$ & $\begin{array}{c}0.666 \\
(0.150-2.961)\end{array}$ & Educational status & $\begin{array}{c}2.000 \\
(0.461-8.677) \\
\end{array}$ & $\begin{array}{c}2.044 \\
(0.419-9.960)\end{array}$ \\
\hline
\end{tabular}

${ }^{*} p<0.05$

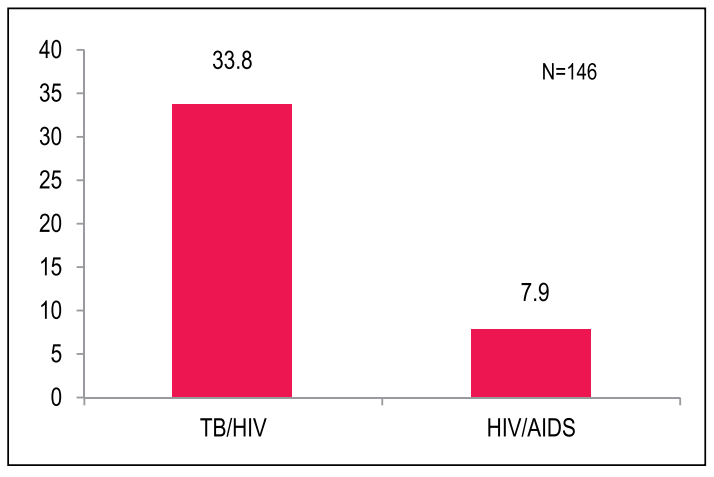

Figure 1. Prevalence of depression among PLHIV and TB/ HIV co-infection

\section{DISCUSSION}

In this study, comparison of the QoL of persons with HIV infection with and without TB was done. The WHOHQoL BREF questionnaire had a good internal consistency to assess the QoL of TBHIV coinfected patients which was similar to the study conducted in Taiwan and Iran. ${ }^{8,9}$ The overall response rate in the study was ninety-four percent which was similar to the study conducted in Croatia and Ethiopia where the response rate was above eighty percent. ${ }^{10,11}$

According to this study, the largest portion of respondents were affected with this disease between 18- 40 years of age and this finding is congruent the report of UNAIDS/WHO Report on the global AIDS epidemic 2008, in 2007 off total about 33 million people of HIV positive, an Estimates 30.8 million people were in the working age group ( $15-49$ years of age). The majority of the respondents were males and this is similar to the research conducted in Bangladesh and Iran. ${ }^{12,13}$ With more urban areas respondents were found to receive levels of secondary education similar to the other study. ${ }^{13}$ Most of the respondents were married and were employed, in contrast with the other studies where most of the respondents were unemployed and separated. A majority of the respondents had a history of opportunistic infection and had CD4 Count more than 350 for PLWHA which was found to be similar to a study conducted in Bangladesh. ${ }^{12}$

The mean score of HQoL was highest in the environmental domain in both groups and the least in physical and overall satisfaction domains in this study, findings similar to the study in Bangladesh ${ }^{12}$, where the mean QoL scores was highest in spiritual/ religion and lowest in the overall satisfaction, but in contrast with the study at Croatia. ${ }^{10}$ TB-HIV coinfected patients had a lower quality of life in all domains as compared to HIV infected patients without TB. ${ }^{11}$ In other studies, it was reported that HIV patients had a lower QoL as compared to the general population ${ }^{14}$ and that TB patients had a lower QoL as compared to their neighbors. ${ }^{15}$

The Bivariate Analysis revealed that CD4 count, educational status, occupation, ethnicity, family size and depression was significantly associated with the QoL domains in the study while an association between CD4 count, WHO staging and other Socio demographic characteristics with QoL was observed in various studies. ${ }^{15,16}$ Similarly, 
Socio-demographic characteristics, such as age, gender, education, income employment status and disease related variables such as disease stage, opportunistic infection, CD4 count etc have been found to be strongly associated with the QoL of PLHIV. ${ }^{17}$ Some researchers have documented low performance for women in some aspects of quality of life ${ }^{18}$ while in some other studies difference according to gender was not found, or have even shown the opposite. Women had poorer QoL compared to men. ${ }^{13}$ Some reports in literature find younger age to be related with better QoL ${ }^{19}$ while in this study gender and sex has no relationship with the quality of life, which is similar to a study conducted at India. ${ }^{20}$ Comparison with the educational status revealed that those with lower secondary and secondary education had better physical health and overall satisfaction whereas contradictory results have been observed in comparisons between educational groups which showed that those with less education reported significantly poorer QoL than those with more education, according to some authors. Likewise, Subjects with higher education reported better QoL in the independence and environment domains. ${ }^{21}$ In this study marital status had no influence on the quality of life domains but marital status influences quality of life; Subjects who are married or in relationship reported a higher level of QoL for the social relationships domain. Those in relationships may enjoy better social support. ${ }^{10}$ Having an occupation or a source of income meant a higher QoL in all the domains except level of independence which was similar to the results of study conducted in Brazil where source of income was associated with a better HQoL only with respect to the physical and psychological domains. Some authors have acknowledged the fact that being employed is the main predictor of the HQoL scales for their population and it has been shown that the HIV-infected patients find it difficult to get and keep jobs. ${ }^{22}$ An association between CD4 count and other Socio demographic characteristics with QoL was observed in this study, in line with various other studies. ${ }^{16,15}$ Studies show that depression affects the quality of life of people living with HIV in many ways, ${ }^{23}$ which coincides with this study where depression had significant association with all the QoL domains except physical health and level of independence.
The prevalence of depression was higher in TBHIV coinfected patients than PLWHA, findings which are similar to the results of a study where TBHIV coinfected patients had significantly greater risk of CMD than the non-co-infected patients. ${ }^{24}$ Clinical Management of TB-HIV co-infection can be complicated and due to the fact that many ART drugs pharmacokinetics and dynamics leads to drug interaction and predisposal symptoms, negative health effects and illness, as HIV leading to weak immune response itself is a risk factor for Neuropsychiatric manifestations..$^{24,25}$ Variations in clinical outcomes of neuropsychiatric manifestations are observed in TB-HIV co-infections and HIV infection only. HIV only people are more symptomatic than in people with TB-HIV co-infection however these manifestations vary with the severity and viral load in the person. ${ }^{26}$

In coinfected patients, individuals who had depression were 8.8 times more likely to have poor physical health as compared to individuals who had no depression ${ }^{11}$ whereas in this study, among coinfected patients, depression was 3.86 times more likely to influence QoL. When adjusted for the effect of potential confounding variables, the odds of having CMD for TB-HIV coinfected individuals was 1.7 times the odds for non-coinfected patient, while in this study adjusted odds was 4.21 times higher. ${ }^{24}$

\section{CONCLUSION}

TB-HIV co-infected patients had a lower quality of life in all domains compared to HIV infected patients without TB. The prevalence of depression was found higher in TB-HIV coinfected people than HIVI AIDS group. The Bivariate Analysis revealed that CD4 count, educational status, occupation, family size and depression were significantly associated with the QoL domains in the study. Gender, sex and marital status had no relationship with the quality of life. A significant association between CD4 counts and depression with QoL was observed with all the domains except physical health and level of independence. Among coinfected patients, depression was 3.86 times more likely to influence QoL,4.21 times higher with adjusted odds. The TB control program should design strategies to improve the quality of life of TB-HIV coinfected 
people and depression should be targeted as an intervention to improve the quality of life of people living with HIV with or without TB.

\section{ACKNOWLEDGEMENTS}

The author acknowledges Nepal Health Research Council for funding the study, Dharma Nand Bhatta Lecturer Nobel College for the supervision, Mr. Shyam Thapa Hospice Incharge Navakiran Plus, Ms Mira Kuwar General Secretary NAP+N and appreciates the study participants for their cooperation in proving necessary information.

\section{REFERENCES}

1. http://www.who.int/tb/dots/en

2. Stop TB Partnership 2006.

3. TB/HIV Co-epidemic in the SAARC region: SAARC-CANADA Regional Tuberculosis and HIV/ AIDS Project; 2003;1-2.

4. http://www.usaid.gov/our_work/global_health/ aids/Countries/ane/nepal.html retrieved 23rd September 2011.

5. World Health Organization. Tuberculosis control in the South- East Asia Region: The Regional Report;2006, SEA.TB.293.

6. Development of the World Health Organization WHOQOL-BREF quality of life assessment. The WHOQOL Group. Psycho Med.1998;28,551-8.

7. Beck AT, CH Ward, M Mendelson, J Mock, J Erbaugh. An inventory for measuring depression. Arch Gen Psychiatry. 1961;4:561-71.

8. Fang C, Hsiung P, Yu C, Chin M, Wang J. Validation of the World Health Organization quality of life instrument in patients with HIV infection. Qual Life Res. 2002;11:753-62.

9. Saharnaz Nedjat S, Montazeri A, Holakouie K, Mohammad K, Reza M. Psychometric properties of the Iranian interview-administered version of the World Health Organization's Quality of Life Questionnaire (WHOQOL-BREF): A populationbased study. BMC Health Services Research. 2008:8:61. Doi: 10.1186/1472-6963-8-61.

10. S. Belak Kovaevi et al. Quality of Life of HIV Infected Persons in Croatia. Coll. Antropol, 2006;30,Suppl. 2, 79-84.
11. Deribew A, Tesfaye $M$, Hailmichael $Y$, et. al., Common mental disorders in TB/HIV coinfected patients in Ethiopia. BMC Infectious Diseases 2010;10:201.

12. Imam, M.H. Karim, M.R. Ferdous, C. Akhter, S. Health related quality of life among the people living with HIV. Bangladesh Med Res Counc Bull.2011;37,1-6.

13. Marzieh, N. Khatereh, A. Mitra, R. Health-Related Quality of Life in Patients with HIVIAIDS. Arch Iranian Med, 2008;11,608-12.

14. Naveet W, Raja L, Hemraj P, Vivek A, Chander M, Sunil A: The impact of HIVIAIDS on the quality of life: A cross sectional study in north India. Indian Jour Med Sciences 2006;60:3-12.

15. Mekasha T, Woldemichael $\mathrm{K}$ : Assessment of patients' health related quality of life during tuberculosis treatment as compared to their neighbours in Hawassa town, Ethiopia [Master's thesis in public health]. Jimma University, Ethiopia; 2009

16. O'Connell K, Skevington S, Saxena S. WHOQoL HIV Group, Preliminary development of the World Health Organization's Quality of Life HIV instrument (WHOQoL-HIV): analysis of the pilot version. Soc Sci Med. 2003;57:1259-75.

17. Basavaraj KH, Navya MA, Rashmi R. Quality of life in HIVIAIDS. Indian J Sex Transm Dis. 2010;31:7580.

18. Lenderking, W. R., M. A. Testa, D. Katzenstein, S. Hammer. Qual Life Res; 1997;6,515.

19. Molassiotis A, Callaghan P, Twinn SF, Lam SW. Correlates of quality of life in symptomatic HIV patients living in Hongkong. AIDS Care. 2001;13:319-334

20. Tiwari MK, Verma S, Agrawal D and Heena. Quality of Life of Patients with HIV Infection. Indian $J$ of Soc. Sci. Res. Oct., 2009;2:79-86.

21. Murri, R., M. Fantoni, C. DEL Borgo, R. Visona, A. Barracco, A. Zambelli, L. Testa, N. Orchi, V. Tozzi, O. Bosco, A. W. WU. 2003;AIDS Care.15, 581.

22. Razera F, Ferreira J, Bonamigo RR. Factors associated with health-related quality-of-life in HIVinfected Brazilians. Int. Journal of STD \& AIDS. 2008;19:519-23.

23. Worthington, C. \& H. Krentz. "Employment status, level of income and quality of life in people living with HIV. Paper presented at the Canadian Association for HIV Research, Montreal.2004. 
24. Deribew A, Tesfaye $M$, Hailmichael $Y$, et.al. Tuberculosis and HIV co-infection: its impact on quality of life. Health and Quality of Life Outcomes. 2009;7:105 doi:10.1186/1477-7525-7-105.

25. Heaton, R.K., et al., HIV-associated neurocognitive disorders before and during the era of combination antiretroviral therapy: differences in rates, nature, and predictors. Journal of NeuroVirology, 2011;3,16-21.

26. Mugusi, S., optimization of HIV and tuberculosis cotreatment in tanzania: drug-drug interactions and clinical outcomes. Department of Clinical Science And Education, Karolinska Institute Sweden, 2013. 